\title{
RESEARCH
}

Open Access

\section{Potential effect of tobacco cigarettes smoking on global DNA methylation status and protamines transcripts in human spermatozoa}

\author{
Mohammed M. Laqqan ${ }^{1 *}$ (D) and Maged M. Yassin²
}

\begin{abstract}
Background: Epigenetics refers to an alteration in gene expression without alteration in the sequence of DNA and this process may be affected by environmental factors and lifestyle like cigarette smoking. This study was designed to evaluate the potential effect of cigarette smoking on the global DNA methylation status and the transcription level of protamine 1 and protamine 2 in human spermatozoa. A total of 188 semen samples were collected from men with a mean age of $34.9 \pm 5.8$ years old (98 heavy smokers and 90 non-smokers). The DNA and RNA were isolated from purified spermatozoa, then the status of global DNA methylation and the transcription level of protamine 1 and protamine 2 were evaluated using ELISA and GPCR, respectively. The chromatin non-condensation and DNA fragmentation in human spermatozoa were evaluated using chromomycin A3 staining and TUNEL assay, respectively.

Results: A significant increase has been found in the status of global DNA methylation in spermatozoa of heavy smokers compared to non-smokers $(7.69 \pm 0.69 \mathrm{ng} / \mu \mathrm{l}$ vs. $4.90 \pm 0.40 \mathrm{ng} / \mu \mathrm{l}, P<0.001)$. Additionally, a significant reduction has been found in transcription level of protamine 1 ( $25.49 \pm 0.31$ vs. $23.94 \pm 0.40, P<0.001)$ and protamine $2(28.27 \pm 0.39$ vs. $23.45 \pm 0.30, P<0.001)$ in heavy smokers. A downregulation has been found in the transcription level of protamine 1 and protamine 2 with a fold change of 0.497 and 0.047 , respectively. A significant increase has been shown in the level of DNA fragmentation and chromatin non-condensation in heavy smokers compared to non-smokers $(P<0.001)$. On the other hand, a significant positive correlation has been found between sperm chromatin non-condensation, sperm DNA fragmentation, transcription level of protamine 1, transcription level of protamine 2 , and global DNA methylation status $(r=0.304, P<0.001 ; r=0.399, P<0.001 ; r=0.216, P=0.003 ; r=0.494, P<0.001$, respectively).
\end{abstract}

Conclusion: Tobacco cigarette smoking has a potential influence on the global DNA methylation and the transcription level of protamine genes in human spermatozoa, and consequently, affect negatively on the semen parameters.

Keywords: Global methylation, Heavy smoking, Human spermatozoa, Protamines

\footnotetext{
* Correspondence: m.laqqan@gmail.com

${ }^{1}$ Faculty of Health Sciences, Department of Medical Laboratory Sciences,

Islamic University, Gaza, Palestinian Territories

Full list of author information is available at the end of the article
} 


\section{Background}

Epigenetics is defined as an alteration in gene expression without alteration in the sequence of DNA [1]. Epigenetics includes modifications to histone proteins, DNA methylation, and non-coding RNA action [2]. DNA methylation is a major epigenetic modification involving the addition of a methyl $\left(\mathrm{CH}_{3}\right)$ group to the fifth position of cytosine nucleotide $[3,4]$ by DNA methyltransferase (DNMTs) to form 5-methylcytosine $(5-\mathrm{mC})[5,6]$. The process of DNA methylation plays a critical role in various cellular processes for example $\mathrm{X}$-chromosome inactivation, genomic imprinting, silencing of transposons, and regulation of gene expression [7]. Several previous studies have reported that gene silencing is associated with an increase in DNA methylation level $[8,9]$. Epigenetics may be impacted by lifestyle and environmental factors [10], where cigarette smoking was classified as the most lifestyle that impact the epigenetic and the transcription level of genes [11, 12]. Cigarette smoke can alter DNA methylation through different mechanisms. First, DNA damage and subsequent recruitment of DNMTs [13]. Second, the influence of nicotine on the gene expression level at spermatozoa [14]. Third, it may alter the DNA methylation through the modulation of gene expression and the activity of DNAbinding factor indirectly [15]. On the other hand, the oxidative stress resulting from cigarette smoking can contribute to the loss of DNA methylation by the hydroxylation of 5-methylcytosine to form 5-hydroxymethylcytosine [16]. In addition, reactive oxygen species (ROS) can influence DNA methylation by acting on the activity and expression of DNMTs [17]. Several previous studies have evaluated whether there is an association between the alterations of DNA methylation, the transcription level of protamine in human spermatozoa, and cigarette smoking; one of these studies reported that an increase in the level of reactive oxygen species found in cigarette smoke leads to variation in the transcription level of protamines $[18,19]$. Moreover, previous studies have been found a strong association between the reduction in the semen parameters, a decline in the sperm DNA integrity, elevation in the spermatozoa DNA damage, a change in the DNA methylation patterns, and cigarette smoking [20-24]. Another previous study found that the status of DNA methylation and the expression level of genes may be changed by smoking or exposure to cigarette smoke [25]. Nevertheless, people still consume cigarettes on a regular and continuous basis. Finally, the effect of cigarette smoking on the status of global DNA methylation, the transcription level of protamines, and the semen parameters remains a highly controversial issue [26-28].

This study was performed to (I) evaluate the potential effect of cigarette smoking on the status of global DNA methylation in human spermatozoa by comparison between the global DNA methylation level in heavy smokers and non-smokers men, (II) determine whether the transcription level of the protamine 1 (PRM1) and protamine 2 (PRM2) is different in heavy smokers compared to non-smokers, and to (III) study the correlation between the change in the status of global DNA methylation and the other parameters that were investigated.

\section{Methods \\ Study population}

A total of 188 semen samples were collected between October 2014 and December 2015 from males with a mean age of $34.9 \pm 5.8$ years. The men were classified into two groups according to the status of cigarette smoking: (I) heavy smokers group $(n=98)$, those who smoke $\geq 25$ cigarettes/day, smoke duration at least 10 years and they still smoking, and (II) non-smokers group, who have never smoked cigarettes in any form during his life $(n=90)$. The sample size calculations were based on the formula for case-control studies. EPIINFO statistical package version 3.5.1 was used with $95 \% \mathrm{CI}, 80 \%$ power, and $50 \%$ proportion as conservative and $\mathrm{OR}>2$. The exclusion criteria for participation in this study were as follows: diabetes mellitus, alcohol intake, Varicocele, Y chromosome microdeletions, abnormal body mass index, abnormality in hormonal levels, and occupational exposures to known reproductive toxins or excessive heat. In contrast, the inclusion criteria were as follows: males from the same ethnicity and nationality, males have the same food supplementation or a good nutritional status, and non-smokers who have had one child at least.

\section{Sample collection and preparation}

The semen samples were collected by masturbation after 3 days of abstinence from sexual intercourse. The samples were allowed to liquefy for $30 \mathrm{~min}$ at 37 ${ }^{\circ} \mathrm{C}$. Then, the Makler Chamber was used to evaluate the sperm count (Sefi-Medica, Haifa, Israel). The semen parameters were analyzed according to the World Health Organization guidelines [29]. All of the semen samples underwent the protocol of Somatic Cell Lysis Buffer (SCLB) to remove the somatic cells before the DNA extraction step from spermatozoa. Briefly, the liquefied semen samples were loaded onto $40 \%$ over $90 \%$ discontinuous Puresperm gradients (Nidacon International $\mathrm{AB}$, Sweden) and then centrifuged at $500 \times g$ for $25 \mathrm{~min}$ at room temperature. After that, the pure spermatozoa were incubated with SCLB on ice for $30 \mathrm{~min}$ and washed three times with phosphate-buffered saline (PBS), and then centrifuged at $500 \times g$ for $10 \mathrm{~min}$ [30, 31]. Finally, the microscopic examination was used to prove the purity of the semen samples from somatic cells and other debris. 


\section{Evaluation of sperm chromatin condensation}

The chromomycin A3 (CMA3) staining was used to evaluate the chromatin non-condensation at human spermatozoa. Briefly, four semen smears were prepared from each sample and all smears were fixed by using a fixative solution (methanol-glacial acetic acid, 3:1 respectively) at $4{ }^{\circ} \mathrm{C}$ for $20 \mathrm{~min}$. The semen smears were air-dried at room temperature. After that, each smear was covered by $50 \mu \mathrm{l}$ of staining solution (Sigma-Aldrich, St. Louis, MO, USA) and then incubated in a dark place at room temperature for $20 \mathrm{~min}$. The phosphatebuffered saline (PBS) was used to wash all the slides, then the slides were mounted with 1:1 (v/v) glycerol/PBS incubated overnight at $4{ }^{\circ} \mathrm{C}$. To estimate the results of CMA3 staining, the fluorescence microscope (Zeiss Photomicroscope III, Germany) was used to analyze 200 spermatozoa on each smear. Finally, the CMA3 staining was evaluated by differentiating the spermatozoa that stained with bright yellow (positive, bad spermatozoa) from spermatozoa that stained with a dull yellow (negative, good spermatozoa) [32].

\section{Evaluation of DNA fragmentation of human spermatozoa}

The DNA fragmentation of spermatozoa (sperm apoptosis) was assessed using the terminal deoxyribonucleotide transferase-mediated dUTP nick-end labeling (TUNEL) assay [33]. The TUNEL assay was performed by using the in situ cell death detection kit following the guidelines of the manufacturer company (Roche Diagnostics GmbH, Mannheim, Germany). Briefly, Smears were prepared using $10 \mu \mathrm{l}$ of sperm suspension on microscope slides and allowed to air-dry and then fixed with $4 \%$ paraformaldehyde phosphate-buffered saline, $\mathrm{pH} 7.4$ for $2 \mathrm{~h}$ at room temperature, then rinsed with PBS. Smears were then permeabilized with $0.1 \%$ Triton $\mathrm{X}-100$ in $0.1 \%$ sodium citrate, $\mathrm{pH} 6.0$ for $15 \mathrm{~min}$ at room temperature; $50 \mu \mathrm{l}$ of the TdT-labeled nucleotide mixture ( $50 \mu \mathrm{l}$ of enzyme solution and $450 \mu \mathrm{l}$ of label solution) was added to each slide and incubated in a humidified chamber at $37^{\circ} \mathrm{C}$ overnight in the dark. Negative controls without TdT enzyme were run in each replicate. Then, slides were rinsed two times in PBS and left to dry in the air followed by adding $25 \mu \mathrm{l}$ of 5 $\mu \mathrm{g} / \mathrm{ml}$ DAPI stain solution to each slide as a counterstain and then covered by coverslips. For evaluation, a total of 500 spermatozoa were analyzed on each slide, by distinguishing spermatozoa stained bright green (TUNEL positive, fragmented DNA) from those stained dull green (TUNEL negative, with intact DNA). A Zeiss Photomicroscope III was used for the fluorochrome evaluation (Zeiss Photomicroscope III, Germany) [34].

\section{Nucleic acid isolation from human spermatozoa}

The DNA and RNA were isolated from the human spermatozoa by using Isolate II DNA/RNA/Protein Kit and all steps were performed according to the guidelines of the manufacturer company (Bioline, UK). The Nanodrop spectrophotometer-2000c (Thermo Scientific, USA) was used to evaluate the purity and the quantity of isolated nucleic acid in order to ensure that the isolated nucleic acid is sufficient and suitable for global sperm DNA methylation and qPCR.

\section{Global DNA methylation}

The MethylFlash ${ }^{\mathrm{TM}}$ Methylated DNA Quantification ELISA Kit was used to evaluate the level of global DNA methylation (5-methylcytosine) in the human spermatozoa, and all the steps were performed according to the manufacturer's guidelines (Epigentek Group Inc., USA). Briefly, $100 \mathrm{ng}$ of extracted DNA was incubated with the DNA-binding buffer solution at $37{ }^{\circ} \mathrm{C}$ for $90 \mathrm{~min}$ (the blank, a positive and negative control have been used in triplicate during this assay). After washing the microwell three times, the methylated DNA capture solution was added to each well and incubated for $1 \mathrm{~h}$ at room temperature. After that, the detection antibodies were added to each well and incubated at room temperature for $30 \mathrm{~min}$. After washing three times, the developing solution was added to each well and incubated at room temperature in the dark place for $10 \mathrm{~min}$, and at the end of the $10 \mathrm{~min}$, the stop solution was added. The microplate ELISA reader was used to assess the absorbance at $450 \mathrm{~nm}$. The global DNA methylation status (ng) was calculated using the equation: $5-\mathrm{mC}(\mathrm{ng})=[($ sample $\mathrm{OD}$ - blank OD)/100].

\section{Reverse transcription and qPCR}

The extracted RNA from human spermatozoa was converted to complementary DNA (cDNA) in a $30-\mu$ l reaction volume by using the miScript reverse transcription kit and all procured following the manufacturer's guidelines (Qiagen, Germany). The transcription level of protamine 1 (PRM1), protamine 2 (PRM2), and the housekeeping gene as a reference gene $(G A P D H)$ were evaluated by using the qPCR instrument (7500 Fast applied Bio-systems, USA). The cDNA was used as a template, and all the primers included in this study (QuantiTect Primer) were used according to the guidelines of the manufacturer company (Qiagen, Germany). The reverse transcriptase control (NRT) and template control (NTC) were not involved in runs. All samples were analyzed in triplicate, and all the values of $C_{t}$ were normalized to GAPDH.

\section{Data analysis}

The data of this study were analyzed using SPSS version 24.0 (SPSS Inc., USA). All samples included in this study were non-normally distributed (nonparametric) and that depending on the results of the skewness test, the 
Kurtosis test, $\mathrm{Z}$ value, and Shapiro test. Consequently, the independent-sample $t$ test (Mann-Whitney $U$ test) was used to compare the means of quantitative variables between the study groups. Spearman's test was used to assess the association between the global DNA methylation, the transcription level of protamine, and semen parameters. The comparative $\Delta C_{t}$ method was used separately to calculate the relative RNA quantity in all samples. The $\Delta \mathrm{C}_{\mathrm{t}}$ was calculated by subtracting the $\mathrm{C}_{\mathrm{t}}$ values of GAPDH from the $\mathrm{C}_{\mathrm{t}}$ values of the target RNA, where $\Delta C_{t}=\left(\left[C_{t}\right.\right.$ RNA of protamine $]-\left[C_{t}\right.$ RNA of $G A P D H])$. Then, the $\Delta \Delta C_{t}$ was calculated by subtracting the mean $\Delta C_{t}$ of the control group from the $\Delta C_{t}$ of the cases group $\left(\Delta \Delta C_{t}=\Delta C_{t}\right.$ of heavy smokers $-\Delta C_{t}$ of non-smokers). The fold change of transcription level was calculated by using the following equation: $2^{-\Delta \Delta C t}$ equation [35]. All the results of the above-mentioned tests were considered statistically significant when $p<0.05$.

\section{Results}

The age of the males included in the study population was between 25.0 and 45.0 years, with a mean age of $34.9 \pm 5.8$ years. Table 1 illustrates the descriptive characteristics of the study population. As shown in Table 2, a significant decrease has been found in sperm count $(P$ $=0.003)$, percentage of total sperm motility $(P<0.001)$, progressive motility $(P<0.001)$, normal form $(P<0.001)$, and semen volume $(P<0.001)$ in heavy smokers compared to non-smokers males. Conversely, a significant increase has been observed in percentage of sperm nonprogressive motility $(P<0.001)$, non-motile $(P<0.001)$, and abnormal form $(P<0.001)$ in heavy smokers compared to non-smoker groups. A significant increase was found in the level of chromatin non-condensation (33.30 \pm 2.26 vs. $19.32 \pm 1.13 ; P<0.001)$ and the level of DNA fragmentation $(26.68 \pm 2.00$ vs. $11.66 \pm 1.02 ; P<0.001)$ in spermatozoa of heavy smokers compared to non-smokers (Fig. 1).

\section{Global DNA methylation and protamines transcription}

As illustrated in Fig. 1, a significant increase has been found in the status of global DNA methylation at spermatozoa of heavy smokers compared to non-smokers $(7.69 \pm$ $0.69 \mathrm{ng} / \mu \mathrm{l}$ vs. $4.90 \pm 0.40 \mathrm{ng} / \mu \mathrm{l}, P<0.001)$. A significant reduction has been found in heavy smokers compared to non-smokers in the transcription level of protamine 1 $(25.49 \pm 0.31$ vs. $23.94 \pm 0.40, P<0.001)$ and transcription level of protamine $2(28.27 \pm 0.39$ vs. $23.45 \pm 0.30, P<$ 0.001) (Fig. 2). These results showed a downregulation in the transcription level of protamine 1 and protamine 2 with a fold change of 0.497 and 0.047 , respectively, in the heavy smokers compared to the non-smoker (Table 3).

\section{Correlation between the global DNA methylation and semen parameters}

Table 4 showed a negative significant correlation between sperm concentration $(r=-0.189 ; P=0.009)$, the percentage of total sperm motility $(r=-0.303 ; P<0.001)$, progressive motility $(r=-0.514 ; P<0.001)$, normal form $(r$ $=-0.498 ; P<0.001)$, and the status of global DNA methylation in human spermatozoa. In contrast, a positive significant correlation has been found between the percentage of sperm non-progressive motility $(r=0.314 ; P<0.001)$, nonmotile sperm $(r=0.303 ; P<0.001)$, sperm abnormal form $(r=0.498 ; P<0.001)$, level of chromatin non-condensation $(r=0.304 ; P<0.001)$, DNA fragmentation level $(r=0.399$; $P<0.001)$, and the global DNA methylation status.

\section{Correlation between protamines transcription level and semen parameters}

As indicated in Table 5, a significant positive correlation has been found between the transcription level of protamine

Table 1 Descriptive characteristics of the study population $(n=188)$

\begin{tabular}{|c|c|c|c|c|}
\hline Variables & Mean & Median & SD & Range \\
\hline Semen volume $(\mathrm{ml})$ & 3.74 & 3.50 & 2.06 & 11.30 \\
\hline Sperm concentration (Mill/ml) & 84.17 & 67.00 & 63.54 & 284.00 \\
\hline Total sperm motility (\%) & 47.51 & 48.00 & 21.19 & 89.00 \\
\hline Sperm progressive motility (\%) & 27.75 & 24.00 & 20.75 & 80.00 \\
\hline Sperm non-progressive motility (\%) & 19.76 & 16.00 & 13.33 & 72.00 \\
\hline Non-motile sperm (\%) & 52.49 & 52.00 & 21.19 & 89.00 \\
\hline Sperm normal form (\%) & 10.84 & 6.00 & 11.48 & 53.00 \\
\hline Sperm abnormal form (\%) & 89.16 & 94.00 & 11.48 & 53.00 \\
\hline Sperm chromatin non-condensation (CMA3-positive) & 26.61 & 23.00 & 19.03 & 98.00 \\
\hline Sperm DNA fragmentation (TUNEL-positive) & 19.49 & 12.50 & 17.43 & 97.00 \\
\hline Global DNA methylation level (ng/ $/ \mathrm{l})$ & 6.36 & 6.60 & 1.51 & 5.10 \\
\hline
\end{tabular}

$S D$ standard deviation 
Table 2 Descriptive characteristics of heavy smokers compared to non-smokers ( $n=188$ )

\begin{tabular}{llll}
\hline Variables & $\begin{array}{l}\text { Heavy smoker } \\
(\boldsymbol{n}=\mathbf{9 8})\end{array}$ & $\begin{array}{l}\text { Non-smoker } \\
(\boldsymbol{n}=\mathbf{9 0})\end{array}$ & $\boldsymbol{P}$ value \\
\hline Semen volume (ml) & $3.17 \pm 0.15$ & $4.35 \pm 0.25$ & $<0.001$ \\
Sperm concentration (Mill/ml) & $70.46 \pm 5.62$ & $99.10 \pm 7.21$ & 0.003 \\
Total sperm motility (\%) & $40.34 \pm 2.05$ & $55.32 \pm 2.05$ & $<0.001$ \\
Sperm progressive motility (\%) & $15.78 \pm 1.18$ & $40.79 \pm 2.18$ & $<0.001$ \\
Sperm non-progressive motility (\%) & $24.56 \pm 1.48$ & $14.53 \pm 0.97$ & $<0.001$ \\
Non-motile sperm (\%) & $59.66 \pm 2.05$ & $44.68 \pm 2.05$ & $<0.001$ \\
Sperm normal form (\%) & $4.32 \pm 0.30$ & $17.93 \pm 1.37$ & $<0.001$ \\
Sperm abnormal form (\%) & $95.68 \pm 0.30$ & $82.07 \pm 1.37$ & $<0.001$ \\
\hline
\end{tabular}

All values presented as mean \pm standard error; $P>0.05$ not significant, $P<0.05$ significant

1 and protamine 2 with the level of global DNA methylation ( $r=0.216, P=0.003 ; r=0.494, P<0.001$, respectively). Moreover, protamine 1 and protamine 2 showed significant positive correlations with percentage of sperm nonprogressive motility $(r=0.175, P=0.016$ and $r=0.245, P<$ 0.001 , respectively); non-motile sperm $(r=0.290, P<0.001$ and $r=0.289, P<0.001)$; sperm abnormal form $(r=0.464, P$ $<0.001$ and $r=0.502, P<0.001)$; level of chromatin noncondensation $(r=0.195, P=0.007$ and $r=0.261, P<0.001)$, and level of DNA fragmentation $(r=0.153, P=0.037$ and $r$ $=0.311, P<0.001$, respectively).

In contrast, a significant negative correlation has been observed between the transcription level of protamine 1 and protamine 2 with percentage of total sperm motility $(r=-0.290, P<0.001$ and $r=-0.289, P<0.001$, respectively); progressive motility $(r=-0.425, P<0.001$ and $r=-$ $0.459, P<0.001)$; and normal form $(r=-0.464, P<0.001$ and $r=--0.502, P<0.001$, respectively). However, only

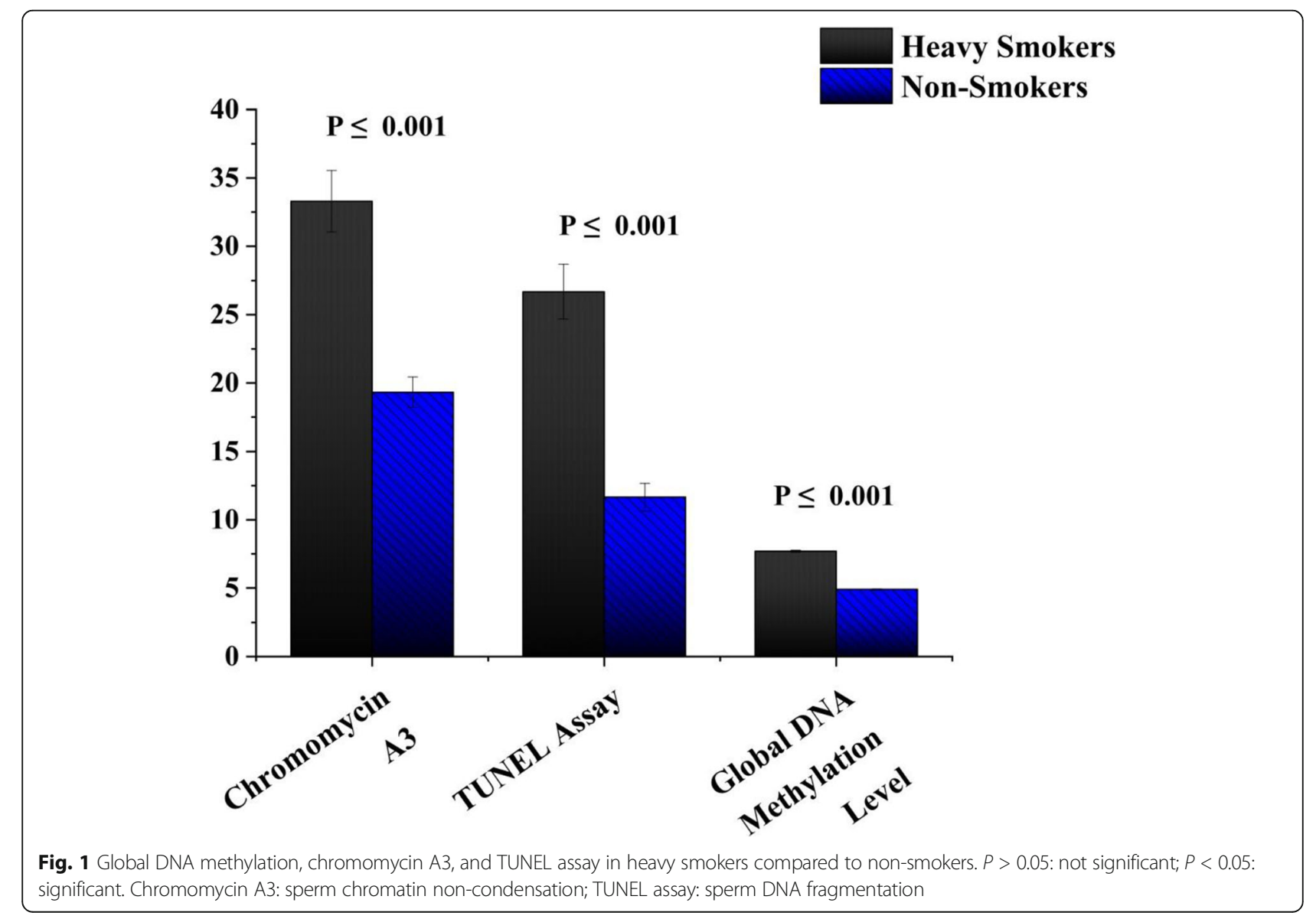




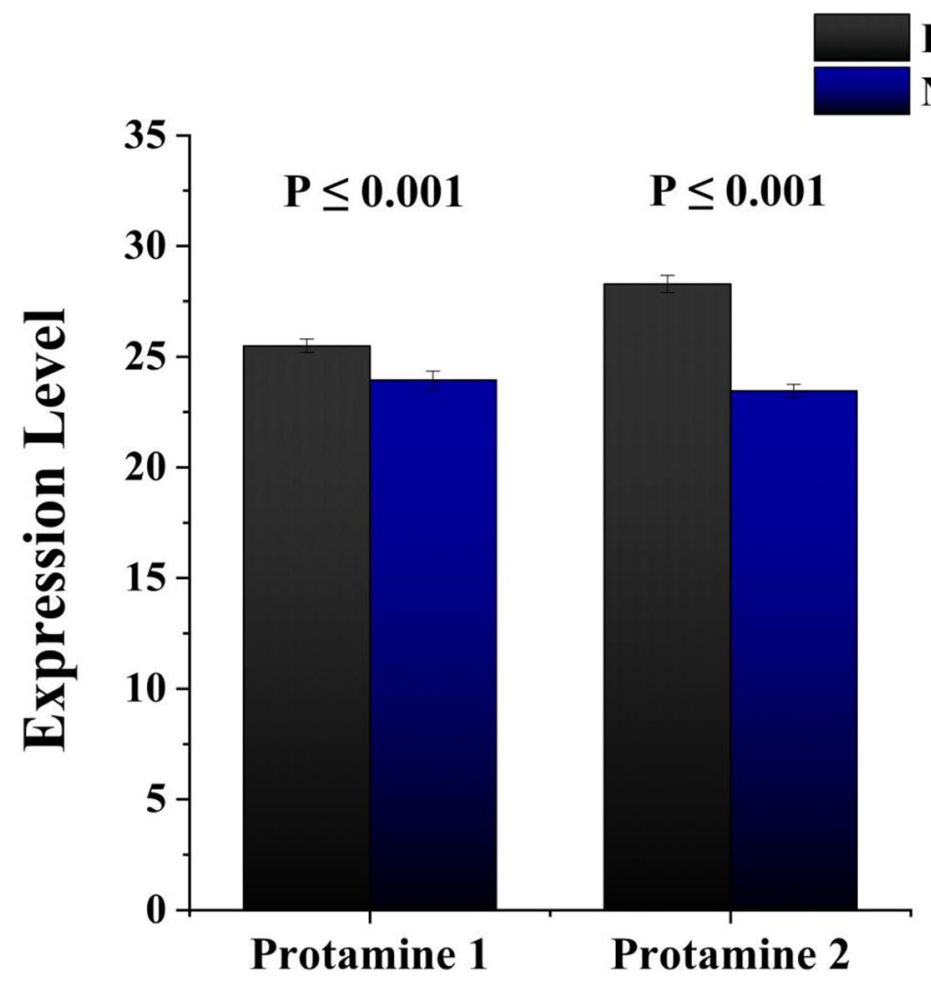

Fig. 2 Transcription level of protamine genes ( 1 and 2 ) in heavy smokers compared to non-smokers. $P>0.05$ : not significant; $P<0.05$ : significant. $C_{t}$ levels are inversely proportional to the amount of target RNA in the sample

protamine 2 transcription level displayed a negative significant correlation with sperm count $(r=-0.215$ and $P=$ 0.003).

\section{Discussion}

This study was performed to evaluate the potential impact of cigarette smoking on the status of global DNA methylation and transcription level of protamine 1 and 2 in human spermatozoa. In humans, many histone variants are expressed during spermatogenesis and modulate the chromatin structure to facilitate the histone-toprotamine replacement to provide a full-function spermatozoon [36]. Consequently, any defect in the process of protamination leads to incorrect packaging of the sperm chromatin and makes the sperm more sensitive to DNA fragmentation, and that occurs through the high levels

Table 3 Transcription levels of PRM1 and PRM2 genes in spermatozoa of heavy smokers compared to non-smokers $(n=188)$

\begin{tabular}{lll}
\hline Variables & PRM1 $\left(\Delta C_{t}\right)$ & $P R M 2\left(\Delta C_{t}\right)$ \\
\hline Heavy smoker & 1.17 & 3.95 \\
Non-smokers & 0.16 & -0.47 \\
$\Delta \triangle C_{t}$ & 1.01 & 4.42 \\
Fold change & 0.497 & 0.047 \\
Regulation & Down & Down \\
\hline
\end{tabular}

$\Delta C_{t}$ delta cycle threshold of ROS which might be coming from cigarette smoking [37]. The results of this study are consistent with previous studies that have found a significant elevation in the level of global DNA methylation in heavy smokers spermatozoa compared to non-smokers spermatozoa $[24,38]$. Additionally, another study was shown a significant difference in the methylation level of $\mathrm{CpGs}$ that related to the MAPK8IP and TKR genes in the current smokers compared to the never smokers [39]. On contrary, a previous study pointed out no significant variation in the global DNA methylation level between smokers and non-smokers groups [40]. On the other hand, the present study found a significant variation in the transcription level of protamine genes in heavy smokers compared to non-smokers, and these results are consistent with the study performed by Hamad and his colleagues who observed that the transcription level of protamine genes (PRM 1 and PRM 2) in smoker males was significantly lower than the non-smokers [41]. Besides, another study has shown an alteration in the level of protamine gene transcription and DNA methylation in males who smoke tobacco [25]. The results of this study have supported the hypothesis proposed by Afanas'ev who pointed that the enzymes that regulate DNA methylation (DNMT) can be activated by tobacco smoking [42]. In the present study, a significant increase was observed in heavy smokers compared to non- 
Table 4 Correlation between the status of global DNA methylation and semen parameters

\begin{tabular}{lll}
\hline Variables & \multicolumn{2}{l}{$\begin{array}{l}\text { Global DNA methylation } \\
\text { level }(\mathbf{n g} / \boldsymbol{\mu l})\end{array}$} \\
\cline { 2 - 3 } & $\mathbf{r}$ & $\boldsymbol{P}$ value \\
\hline Sperm concentration (Mill/ml) & -0.189 & 0.009 \\
Total sperm motility (\%) & -0.303 & $<0.001$ \\
Sperm progressive motility (\%) & -0.514 & $<0.001$ \\
Sperm non-progressive motility (\%) & 0.314 & $<0.001$ \\
Non-motile sperm (\%) & 0.303 & $<0.001$ \\
Sperm normal form (\%) & -0.498 & $<0.001$ \\
Sperm abnormal form (\%) & 0.498 & $<0.001$ \\
Sperm chromatin non-condensation & 0.304 & $<0.001$ \\
(CMA3-positive) & & $<0.001$ \\
Sperm DNA fragmentation & 0.399 & \\
(TUNEL-positive) & &
\end{tabular}

Spearman's test, $r$ correlation coefficient; $P>0.05$ not significant, $P<$ 0.05 significant

smokers in each of the following parameters: chromatin non-condensation, DNA fragmentation, non-progressive motile, non-motile sperm, and sperm abnormal form, and these findings are matching with the results of previous studies [18, 43, 44]. Additionally, another study found an increase in the rate of cigarette smoking associated with a decline in sperm count, sperm motile, and semen volume [45]. Several studies showed that the substances in the cigarettes may cause insufficiency in spermatogenesis, an increase in the DNA fragmentation in sperm, a reduction in the chromatin condensation, and a decline in sperm count and motility [46, 47]. However, the results of the present study did not match with the previous studies that showed a non-significant increase in the level of DNA fragmentation in smoker males $[48,49]$. Conversely, the results revealed a significant decline in heavy smokers compared to nonsmokers in the following parameters: sperm count, total motility, progressive motility, and sperm normal form. This agrees with previous studies showing a significant reduction in the semen parameters in smokers males compared to non-smokers [42, 50].

A positive significant association was shown between the global DNA methylation status and semen parameters (sperm non-motility, non-progressive motility, and abnormal form); these results are matching with other studies that observed a positive significant correlation between the variation in DNA methylation level and the semen parameters abnormality [51, 52]. A significant positive correlation has been observed between the chromatin non-condensation, DNA fragmentation, and global DNA methylation level and these results coincide with a study that pointed out that, the increase in the methylation level at spermatozoa may lead to an increase the spermatozoa chromatin instability [53]. In contrast, previous studies observed a negative correlation between chromatin abnormalities and the change in sperm DNA methylation [54, 55]. One of the possible explanations for these findings is that the alterations in the global DNA methylation level under the effect of cigarette smoke lead to less chromatin compaction in spermatozoa. Consequently, the rate of sperm DNA fragmentation and sperm DNA exposure to damage will be increased.

On the other hand, a significant positive correlation has been found between protamines transcription and the status of global DNA methylation and these findings are in agreement with previous studies that found a significant relationship between the level of DNA methylation and genes transcription level at human spermatozoa [56, 57]. Conversely, other studies did not support this type of association $[58,59]$. A significant correlation has

Table 5 Correlation between the transcription level of protamines and semen parameters

\begin{tabular}{|c|c|c|c|c|}
\hline \multirow[t]{2}{*}{ Variables } & \multicolumn{2}{|c|}{ PRM1 transcription level } & \multicolumn{2}{|c|}{$\begin{array}{l}\text { PRM2 transcription } \\
\text { level }\end{array}$} \\
\hline & $r$ & $P$ value & $\mathbf{r}$ & $P$ value \\
\hline Sperm concentration (Mill/ml) & -0.139 & 0.057 & -0.215 & 0.003 \\
\hline Total sperm motility (\%) & -0.290 & $<0.001$ & -0.289 & $<0.001$ \\
\hline Sperm progressive motility (\%) & -0.425 & $<0.001$ & -0.459 & $<0.001$ \\
\hline Sperm non-progressive motility (\%) & 0.175 & $<0.016$ & 0.245 & $<0.001$ \\
\hline Non-motile sperm (\%) & 0.290 & $<0.001$ & 0.289 & $<0.001$ \\
\hline Sperm normal form (\%) & -0.464 & $<0.001$ & -0.502 & $<0.001$ \\
\hline Sperm abnormal form (\%) & 0.464 & $<0.001$ & 0.502 & $<0.001$ \\
\hline Sperm chromatin non-condensation (CMA3-positive) & 0.195 & 0.007 & 0.261 & $<0.001$ \\
\hline Sperm DNA fragmentation (TUNEL-positive) & 0.153 & 0.037 & 0.311 & $<0.001$ \\
\hline Global DNA methylation level (ng/ $\mu$ l) & 0.216 & 0.003 & 0.494 & $<0.001$ \\
\hline
\end{tabular}

Spearman's test; $r$ correlation coefficient, $P>0.05$ not significant, $P<0.05$ significant 
been found between PRM 1, PRM 2 transcription levels, and the semen parameters (sperm count, total sperm motility, progressive motility, and sperm normal form), and these results are in the line with the previous studies that showed a negative significant association between the PRM 1/PRM 2 mRNA ratios and the same semen parameters $[19,60]$. Therefore, all of these significant associations between the global DNA methylation, the transcription level of $P R M 1, P R M 2$, and semen parameters in smoker men support the hypothesis proposing that tobacco smoking has a negative influence on the semen parameters and might cause alterations in global DNA methylation and in the transcription levels of protamines which can affect the functions and capacities of spermatozoa.

\section{Conclusion}

The results of this study offer proof that tobacco cigarette smoking has a potential influence on the global DNA methylation and the transcription level of protamine genes in human spermatozoa, and consequently, impact negatively on the semen parameters.

\section{Abbreviations}

ROS: Reactive oxygen species; DNMTs: DNA methyltransferase;

TNP: Transition nuclear proteins; PRM 1: Protamine 1; PRM 2: Protamine 2;

SCLB: Somatic cell lysis buffer; PBS: Phosphate-buffered saline;

CMA3: Chromomycin A3 staining; NRT: No reverse transcriptase control;

NTC: No template control

\section{Acknowledgements}

The authors would like to express their gratitude to all the doctors and clinical staff in the Al Bassma Fertility Center in the Palestinian Territories.

\section{Authors' contributions}

M. M. L collected and processed the samples and data analysis, and he was a major contributor in writing the manuscript. M. M. Y performed a review for data analysis, discussion preparation, and the writing of the manuscript. All authors read and approved the final manuscript.

\section{Funding}

No funding was received for this study.

\section{Availability of data and materials}

The datasets used and/or analyzed during the current study available from the corresponding author on reasonable request.

\section{Declarations}

\section{Ethics approval and consent to participate}

This study was approved by the Palestinian Health Research Council (Reference No. PHRC/HC/13/14) and consent was provided according to the Declaration of Helsinki Committee. Besides, all participants signed an informed approval form to participate in this study. The samples were analyzed according to the guidelines and standard procedures of Al Basma Fertility Center.

\section{Consent for publication}

Not applicable.

\section{Competing interests}

The authors declare that they have no competing interests.

\section{Author details}

${ }^{1}$ Faculty of Health Sciences, Department of Medical Laboratory Sciences, Islamic University, Gaza, Palestinian Territories. ${ }^{2}$ Faculty of Medicine,

Department of Physiology, Islamic University, Gaza, Palestinian Territories.

Received: 24 November 2020 Accepted: 30 June 2021

Published online: 09 July 2021

\section{References}

1. Portela A, Esteller M (2010) Epigenetic modifications and human disease. Nat Biotechnol 28(10):1057-1068. https://doi.org/10.1038/nbt.1685

2. Feng S, Jacobsen SE, Reik W (2010) Epigenetic reprogramming in plant and animal development. Science 330(6004):622-627. https://doi.org/10.1126/ science.1190614

3. Rakyan VK, Down TA, Balding DJ, Beck S (2011) Epigenome-wide association studies for common human diseases. Nat Rev Genet 12(8):529-541. https:// doi.org/10.1038/nrg3000

4. Jenkins TG, James ER, Alonso DF, Hoidal JR, Murphy PJ, Hotaling JM, Cairns BR, Carrell DT, Aston KI (2017) Cigarette smoking significantly alters sperm DNA methylation patterns. Andrology 5(6):1089-1099. https://doi.org/1 $0.1111 /$ andr.12416

5. Rang FJ, Boonstra J (2014) Causes and consequences of age-related changes in DNA methylation: a role for ROS? Biology 3(2):403-425. https:// doi.org/10.3390/biology3020403

6. Jones PA (2012) Functions of DNA methylation: islands, start sites, gene bodies and beyond. Nat Rev Genet 13(7):484-492. https://doi.org/10.1038/ nrg3230

7. Hackett JA (1609) Surani MA (2013) DNA methylation dynamics during the mammalian life cycle. Philos Trans R Soc B: Biol Sci 368:20110328

8. Fuks F (2005) DNA methylation and histone modifications: teaming up to silence genes. Curr Opin Genet Dev 15(5):490-495. https://doi.org/10.1016/j. gde.2005.08.002

9. Biermann K, Steger K (2007) Epigenetics in male germ cells. J Androl 28(4): 466-480. https://doi.org/10.2164/jandrol.106.002048

10. Terry MB, Delgado-Cruzata L, Vin-Raviv N, Wu HC, Santella RM (2011) DNA methylation in white blood cells: association with risk factors in epidemiologic studies. Epigenetics 6(7):828-837. https://doi.org/10.4161/epi. 6.7.16500

11. Alegría-Torres JA, Baccarelli A, Bollati V (2011) Epigenetics and lifestyle Epigenomics 3(3):267-277. https://doi.org/10.2217/epi.11.22

12. Lee KW, Pausova Z (2013) Cigarette smoking and DNA methylation. Front Genet 17(4):132

13. Suter M, Abramovici A, Showalter L, Hu M, Do Shope C, Varner M, AagaardTillery K (2010) In utero tobacco exposure epigenetically modifies placental CYP1A1 expression. Metab-Clin Exp 59(10):1481-1490. https://doi.org/10.101 6/j.metabol.2010.01.013

14. Lee EW, D'Alonzo GE (1993) Cigarette smoking, nicotine addiction, and its pharmacologic treatment. Arch Intern Med 153(1):34-48. https://doi.org/10.1 001/archinte.1993.00410010062005

15. Di YP, Zhao J, Harper R (2012) Cigarette smoke induces MUC5AC protein expression through the activation of Sp1. J Biol Chem 287(33):27948-27958. https://doi.org/10.1074/jbc.M111.334375

16. Valinluck V, Sowers LC (2007) Endogenous cytosine damage products alter the site selectivity of human DNA maintenance methyltransferase DNMT1. Cancer Res 67(3):946-950. https://doi.org/10.1158/0008-5472.CAN-06-3123

17. Campos AC, Molognoni F, Melo FH, Galdieri LC, Carneiro CR, D'Almeida V, Correa M, Jasiulionis MG (2007) Oxidative stress modulates DNA methylation during melanocyte anchorage blockade associated with malignant transformation. Neoplasia (New York, NY) 9(12):1111

18. Hammadeh ME, Hamad MF, Montenarh M, Fischer-Hammadeh C (2010) Protamine contents and P1/P2 ratio in human spermatozoa from smokers and non-smokers. Hum Reprod 25(11):2708-2720. https://doi.org/10.1093/ humrep/deq226

19. Yu B, Qi Y, Liu D, Gao X, Chen H, Bai C, Huang Z (2014) Cigarette smoking is associated with abnormal histone-to-protamine transition in human sperm. Fertil Steril 101(1):51-57. https://doi.org/10.1016/j.fertnstert.2013.09.001

20. Asare-Anane H, Bannison SB, Ofori EK, Ateko RO, Bawah AT, Amanquah SD, Oppong SY, Gandau BB, Ziem JB (2016) Tobacco smoking is associated with decreased semen quality. Reprod Health 13(1):90. https://doi.org/10.1186/ s12978-016-0207-z 
21. Mostafa RM, Nasrallah YS, Hassan MM, Farrag AF, Majzoub A, Agarwal A (2018) The effect of cigarette smoking on human seminal parameters, sperm chromatin structure and condensation. Andrologia 50(3):e12910. https://doi.org/10.1111/and.12910

22. Hamad MF, Shelko N, Kartarius S, Montenarh M, Hammadeh ME (2014) Impact of cigarette smoking on histone $(\mathrm{H} 2 \mathrm{~B})$ to protamine ratio in human spermatozoa and its relation to sperm parameters. Andrology 2(5):666-677. https://doi.org/10.1111/j.2047-2927.2014.00245.x

23. Alkhaled $Y$, Laqqan M, Tierling S, Lo Porto C, Amor H, Hammadeh ME (2018) Impact of cigarette-smoking on sperm DNA methylation and its effect on sperm parameters. Andrologia 50(4):e12950. https://doi.org/1 $0.1111 /$ and. 12950

24. Hamad MF, Dayyih WA, Laqqan M, AlKhaled Y, Montenarh M, Hammadeh ME (2018) The status of global DNA methylation in the spermatozoa of smokers and non-smokers. Reprod Biomed Online 37(5):581-589. https:// doi.org/10.1016/j.rbmo.2018.08.016

25. Word B, Lyn-Cook LE Jr, Mwamba B, Wang H, Lyn-Cook B, Hammons G (2013) Cigarette smoke condensate induces differential expression and promoter methylation profiles of critical genes involved in lung cancer in $\mathrm{NL}-20$ lung cells in vitro: short-term and chronic exposure. Int J Toxicol 32(1):23-31. https://doi.org/10.1177/1091581812465902

26. Arabi M, Moshtaghi $H$ (2005) Influence of cigarette smoking on spermatozoa via seminal plasma. Andrologia 37(4):119-124. https://doi.org/1 0.1111/j.1439-0272.2005.00664.x

27. Anderson K, Nisenblat V, Norman R (2010) Lifestyle factors in people seeking infertility treatment-a review. Aust N Z J Obstet Gynaecol 50(1):820. https://doi.org/10.1111/j.1479-828X.2009.01119.x

28. Gunes S, Metin Mahmutoglu A, Arslan MA, Henkel R (2018) Smokinginduced genetic and epigenetic alterations in infertile men. Andrologia 50(9):e13124. https://doi.org/10.1111/and.13124

29. World Health Organization (2010) WHO laboratory manual for the examination and processing of human semen 2010, 5th edn. WHO press, Geneva

30. Sun Z, Zhang W, Xue X, Zhang Y, Niu R, Li X, Li B, Wang X, Wang J (2016) Fluoride decreased the sperm ATP of mice through inhabiting mitochondrial respiration. Chemosphere 144:1012-1017. https://doi.org/10.1 016/j.chemosphere.2015.09.061

31. Laqqan M, Hammadeh ME (2018) Aberrations in sperm DNA methylation patterns of males suffering from reduced fecundity. Andrologia 50(3): e12913. https://doi.org/10.1111/and.12913

32. Zeyad A, Hamad MF, Hammadeh ME (2018) The effects of bacterial infection on human sperm nuclear protamine $\mathrm{P} 1 / \mathrm{P} 2$ ratio and DNA integrity. Andrologia 50(2):e12841. https://doi.org/10.1111/and.12841

33. Borini A, Tarozzi N, Bizzaro D, Bonu MA, Fava L, Flamigni C, Coticchio G (2006) Sperm DNA fragmentation: paternal effect on early post-implantation embryo development in ART. Hum Reprod 21(11):2876-2881. https://doi. org/10.1093/humrep/del251

34. Shamsi MB, Kumar R, Dada R (2008) Evaluation of nuclear DNA damage in human spermatozoa in men opting for assisted reproduction. Indian J Med Res 127(2):115-23

35. Livak KJ, Schmittgen TD (2001) Analysis of relative gene expression data using real-time quantitative PCR and the $2^{-\Delta \Delta C T}$ method. Methods 25(4): 402-408. https://doi.org/10.1006/meth.2001.1262

36. Li Y, Lalancette C, Miller D, Krawetz SA (2008) Characterization of nucleohistone and nucleoprotamine components in the mature human sperm nucleus. Asian J Androl 10(4):535-541. https://doi.org/10.1111/j.17457262.2008.00410.x

37. Erenpreiss J, Spano M, Erenpreisa J, Bungum M, Giwercman A (2006) Sperm chromatin structure and male fertility: biological and clinical aspects. Asian J Androl 8(1):11-29. https://doi.org/10.1111/j.1745-7262.2006.00112.x

38. Kim SK, Jee BC, Kim SH (2015) Histone methylation and acetylation in ejaculated human sperm: effects of swim-up and smoking. Fertil Steril 103(6):1425-1431. https://doi.org/10.1016/j.fertnstert.2015.03.007

39. Laqqan M, Tierling S, Alkhaled Y, Porto CL, Solomayer EF, Hammadeh ME (2017) Aberrant DNA methylation patterns of human spermatozoa in current smoker males. Reprod Toxicol 71:126-133. https://doi.org/10.1016/j. reprotox.2017.05.010

40. Hillemacher T, Frieling H, Moskau S, Muschler MA, Semmler A, Kornhuber J, Klockgether T, Bleich S, Linnebank M (2008) Global DNA methylation is influenced by smoking behaviour. Eur Neuropsychopharmacol 18(4):295298. https://doi.org/10.1016/j.euroneuro.2007.12.005
41. Hamad M, Shelko N, Montenarh M, Hammadeh ME (2019) The impact of cigarette smoking on protamines 1 and 2 transcripts in human spermatozoa. Hum Fertil 22(2):104-110. https://doi.org/10.1080/14647273.2017.1382733

42. Afanas'ev I (2014) New nucleophilic mechanisms of ros-dependent epigenetic modifications: comparison of aging and cancer. Aging Dis 5(1): 52-62. https://doi.org/10.14336/AD.2014.050052

43. Osman K, Mohamed RP, Omar MH, Ibrahim SF, Hashim N (2018) Effect of work stress and smoking towards sperm quality among infertile male. Malays J Public Health Med 2018:33-40

44. Sepaniak S, Forges T, Gerard H, Foliguet B, Bene MC, Monnier-Barbarino P (2006) The influence of cigarette smoking on human sperm quality and DNA fragmentation. Toxicology 223(1-2):54-60. https://doi.org/10.1016/j. tox.2006.03.001

45. Ramlau-Hansen CH, Thulstrup AM, Aggerholm AS, Jensen MS, Toft G, Bonde JP (2007) Is smoking a risk factor for decreased semen quality? A crosssectional analysis. Hum Reprod 22(1):188-196. https://doi.org/10.1093/ humrep/del364

46. Dhabuwala CB, Dunbar JC, Li H, Rajpurkar A, Jiang Y (2002) Cigarette smoking induces apoptosis in rat testis. J Environ Pathol Toxicol Oncol 21(3):243-8

47. Saleh RA, Agarwal A, Sharma RK, Nelson DR, Thomas AJ Jr (2002) Effect of cigarette smoking on levels of seminal oxidative stress in infertile men: a prospective study. Fertil Steril 78(3):491-499. https://doi.org/10.1016/S00150282(02)03294-6

48. Belcheva A, Ivanova-Kicheva M, Tzvetkova P, Marinov M (2004) Effects of cigarette smoking on sperm plasma membrane integrity and DNA fragmentation. Int J Androl 27(5):296-300. https://doi.org/10.1111/j.1365-2 605.2004.00486.x

49. Viloria T, Garrido N, Fernández JL, Remohí J, Pellicer A, Meseguer M (2007) Sperm selection by swim-up in terms of deoxyribonucleic acid fragmentation as measured by the sperm chromatin dispersion test is altered in heavy smokers. Fertil Steril 88(2):523-525. https://doi.org/10.1016/ j.fertnstert.2006.11.135

50. Al Khaled Y, Tierling S, Laqqan M, Lo Porto C, Hammadeh ME (2018) Cigarette smoking induces only marginal changes in sperm DNA methylation levels of patients undergoing intracytoplasmic sperm injection treatment. Andrologia 50(1):e12818. https://doi.org/10.1111/and.12818

51. El Hajj N, Zechner U, Schneider E, Tresch A, Gromoll J, Hahn T, Schorsch M, Haaf T (2011) Methylation status of imprinted genes and repetitive elements in sperm DNA from infertile males. Sex Dev 5(2):60-69. https://doi. org/10.1159/000323806

52. Montjean D, Zini A, Ravel C, Belloc S, Dalleac A, Copin H, Boyer P, McElreavey K, Benkhalifa M (2015) Sperm global DNA methylation level: association with semen parameters and genome integrity. Andrology 3(2): 235-240. https://doi.org/10.1111/andr.12001

53. Olszewska M, Barciszewska MZ, Fraczek M, Huleyuk N, Chernykh VB, Zastavna D, Barciszewski J, Kurpisz M (2017) Global methylation status of sperm DNA in carriers of chromosome structural aberrations. Asian J Androl 19(1):117-124. https://doi.org/10.4103/1008-682X.168684

54. Benchaib M, Braun V, Ressnikof D, Lornage J, Durand P, Niveleau A, Guerin JF (2005) Influence of global sperm DNA methylation on IVF results. Hum Reprod 20(3):768-773. https://doi.org/10.1093/humrep/deh684

55. Tavalaee M, Razavi S, Nasr-Esfahani MH (2009) Influence of sperm chromatin anomalies on assisted reproductive technology outcome. Fertil Steril 91(4): 1119-1126. https://doi.org/10.1016/j.fertnstert.2008.01.063

56. Lee ST, Xiao Y, Muench MO, Xiao J, Fomin ME, Wiencke JK, Zheng S, Dou X, de Smith A, Chokkalingam A, Buffler P (2012) A global DNA methylation and gene expression analysis of early human B-cell development reveals a demethylation signature and transcription factor network. Nucleic Acids Res 40(22):11339-11351. https://doi.org/10.1093/nar/gks957

57. Laqqan M, Hammadeh ME (2018) Alterations in DNA methylation patterns and gene expression in spermatozoa of subfertile males. Andrologia 50(3): e12934. https://doi.org/10.1111/and.12934

58. Sinclair SH, Yegnasubramanian S, Dumler JS (2015) Global DNA methylation changes and differential gene expression in Anaplasma phagocytophiluminfected human neutrophils. Clin Epigenetics 7(1):77. https://doi.org/10.11 86/s13148-015-0105-1

59. Anastasiadi D, Esteve-Codina A, Piferrer F (2018) Consistent inverse correlation between DNA methylation of the first intron and gene expression across tissues and species. Epigenetics Chromatin 11(1):37. https://doi.org/10.1186/s13072-018-0205-1 
60. Rogenhofer N, Dansranjavin T, Schorsch M, Spiess A, Wang H, von Schönfeldt V, Cappallo-Obermann H, Baukloh V, Yang H, Paradowska A, Chen B (2013) The sperm protamine mRNA ratio as a clinical parameter to estimate the fertilizing potential of men taking part in an ART programme. Hum Reprod 28(4):969-978. https://doi.org/10.1093/humrep/des471

\section{Publisher's Note}

Springer Nature remains neutral with regard to jurisdictional claims in published maps and institutional affiliations.

Submit your manuscript to a SpringerOpen ${ }^{\circ}$ journal and benefit from:

- Convenient online submission

- Rigorous peer review

- Open access: articles freely available online

- High visibility within the field

- Retaining the copyright to your article

Submit your next manuscript at $\boldsymbol{\wedge}$ springeropen.com 